\title{
BIOEDUSCIENCE
}

ISSN: 2614-1558

https://journal.uhamka.ac.id/index.php/bioeduscience

\section{Correlation between Generic Science Skills and Scientific Attitudes on Learning Outcomes}

\author{
Suci Ismiatul Hasanah ${ }^{1}$, Romy Faisal Mustofa ${ }^{1}$, Ryan Ardiansyah ${ }^{1}$ \\ ${ }^{1}$ Siliwangi University, St. Siliwangi No. 24, Tasikmalaya, Indonesia, 46115 \\ * Corespondent email: suciismiatul05@gmail.com
}

\section{ARTICLE INFO}

Article history:

Received: 22 Apr 2020

Accepted: 10 Des 2020

Published: 31 Des 2020

\section{Keywords:}

Correlation;

Generik Science Skills;

Learning Outcomes;

Scientific Attitude

\section{A B S T RACT}

Background: Various factors can support efforts to improve student learning outcomes, including generic science skills and scientific attitudes. The study aims to determine the correlation between generic science skills and scientific attitudes on student learning outcomes. Methods: This research is a correlational study using a dual paradigm design with two independent variables. The sample was that used was 60 people who came from $11^{\text {th }}$ grade of Science Program. Result: The result of this research is that there is a strong and very significant correlation between generic science skills and scientific attitudes towards learning outcomes. This is supported by the data analysis results, namely a significance value of 0.000 and a correlation coefficient of 0.623 . Conclusion: So it can be concluded that generic science skills and scientific attitudes contribute to improving student learning outcomes because students who have generic science skills and an excellent scientific attitude will get optimum learning outcomes. Therefore, generic science skills and scientific attitudes that exist in students must continue to be trained and developed.

\section{Korelasi antara Keterampilan Generik Sains dan Sikap Ilmiah terhadap Hasil Belajar}

\section{A B S T R A K}

Background: Terdapat berbagai macam faktor yang mampu mendukung upaya dalam meningkatkan hasil belajar peserta didik, diantaranya adalah keterampilan generik sains dan sikap ilmiah. Penelitian ini bertujuan untuk mengetahui bagaimana korelasi antara keterampilan generik sains dan sikap ilmiah terhadap hasil belajar peserta didik. Metode: Penelitian ini merupakan penelitian korelasional dengan menggunakan desain paradigma ganda dengan dua variabel bebas. Sampel yang digunakan berjumlah 60 orang yang berasal dari kelas XI Program Sains. Hasil: Hasil dari penelitian ini adalah terdapat korelasi yang kuat serta sangat signifikan antara keterampilan generik sains dan sikap ilmiah terhadap hasil belajar. Hal ini didukung oleh hasil analsis data yakni didapatkan nilai signifikansi sebesar 0,000 dan nilai koefisien korelasi sebesar 0,623. Kesimpulan: Sehingga dapat disimpulkan bahwa keterampilan generik sains dan sikap ilmiah memiliki kontribusi dalam membantu meningkatkan hasil belajar peserta didik, karena peserta didik yang memiliki keterampilan generik sains dan sikap ilmiah yang baik akan memperoleh hasil belajar yang optimal. Oleh karena itu, keterampilan generik sains dan sikap ilmiah yang ada pada diri peserta didik harus terus dilatih dan dikembangkan.

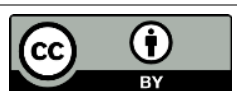

(C) 2020 by authors. License Bioeduscience, UHAMKA, Jakarta. This article is open access distributed under the terms and conditions of a Creative Commons Attribution (CC-BY) license.

\section{Introduction}

Education is held to build and shape people who are knowledgeable and have better mindsets and skills. The ultimate goal of learning is so that students can apply the knowledge that has been obtained in the learning process in everyday life. Yogiharti (2010) explains that "Through meaningful learning, students are expected to be more able to recognize and develop all the knowledge that has been obtained from teaching and learning activities so that the objectives of learning science can be achieved". To achieve this, one way that can be done is to improve students' generic science skills, especially in the Biology subject. Brotosiswoyo (2001) explains that generic science skills are basic scientific skills to solve everyday life problems. Furthermore, Muspiroh (2012) explains that generic 
science skills are known as basic science skills that each individual must possess and need to develop.

Generic science skills can be the basis for students to solve the science problems they face. Following the opinion expressed by Mustofa, A., Suarsini, \& Saptasari (2019), "Generic skills are one of the basic skills that are important in education". Prabowo, Ngazizah, \& Sriyono (2016) explained that "There are skills that train the way of thinking and the skills of students in solving science problems, namely generic science skills". With these skills, learning will be more meaningful because students can develop the knowledge they have. One way to observe the development of generic science skills that students have can be done by looking at the learning outcomes they got.

Gagne (Wahab, 2017) explains "Learning outcomes are abilities that can be observed in a person and also called capabilities". Then Sudjana (2014) argues that "Learning outcomes are the abilities students have after receiving their learning experiences". Learning outcomes that come from interactions between learners and teaching actions must also be continuously developed. One way that can be done is to train students to be able to find facts and concepts by themselves so that the scientific attitudes of students will also develop.

The scientific attitude is the tendency of students to take action to solve scientific problems. According to McIntyre (Hall, 2019) says that "The scientific attitude is everything that is rational, depends on evidence, and is up to date". Likewise with the opinion expressed by Astuti, Sunarno, \& Sudarisman (2012)that "A scientific attitude is a certain attitude taken and developed by scientists to achieve the expected results." Likewise with Sukaesih (2011) which explains that "a scientific attitude is the tendency of individuals to act or behave in solving a problem systematically through scientific steps."

Anwar (2009) explains that "A scientific attitude is a tendency to act in science that affects a person's actions". This tendency to act will have a direct impact on the actions of students in solving science problems in learning. Martiningsih, Situmorang, \& Hastuti (2018) explain that "The level of scientific attitudes possessed by students has a role in the development of learning outcomes". Furthermore, Putri, Idram, \& Yennita (2017) also explained that "The high scientific attitude of a student leads to a higher activity intensity so that learning activities become more active and will get better learning outcomes."

However, from several existing studies, research has not been found that specifically discusses the correlation between generic science skills and scientific attitudes towards student learning outcomes. So it is necessary to do research on the correlation between the three.

One of the concepts in the Biology subject, which is thought to be able to generate generic science skills and develop students' scientific attitudes is the coordination system. Based on the results of an interview with a Biology subject teacher at one of the Tasikmalaya City High Schools, on The Coordination System material, the teacher will instruct students to smell some food with their eyes closed and mention the name of the food ingredient to their colleagues.

In addition, the teacher will also instruct some students to pinch their colleagues' arms and see the responses that will be given. When students carry out these activities, generic science skills and students' scientific attitudes will appear. This situation is supported by the statement (Sadia, 2014) that "The learning process is not just memorizing concepts, but also discovering concepts through one's own experience and applying them to problem-solving in contextual everyday life".

Based on this description, it can be seen that both generic science skills and scientific attitudes both have a contribution to learning outcomes that will be obtained by students. This study aims to determine how the correlation between generic science skills and scientific attitudes toward student learning outcomes.

\section{Methods}

This research's type of research is associative research, namely, by using correlational research methods. Correlation research is a method in which researchers determine the relationship between two or more variables without trying to influence each other. Furthermore, the research design used is a dual paradigm design with two independent variables (Sugiyono, 2012). The sample that used was 60 students from the $11^{\text {th }}$ grade of the Science program. The sample selection that used was the purposive sampling technique.

The study has lasted for approximately six weeks. The author makes observations of all learning activities carried out in each class that is sampled. After the teacher has delivered all the material, the author provides research instruments to students. To obtain the required data, the authors used two types of instruments as primary data, namely test instruments in the form of essay questions to obtain generic science skills data, and non-test instruments in the form of questionnaires to obtain scientific attitude data. Meanwhile, for learning outcomes data taken from secondary data in daily test scores on the Coordination System material.

Furthermore, data analysis was performed using SPSS version 26 for Windows, with a prerequisite test consisting of the Kolmogorov-Smirnov test for normality test, followed by a linearity test. Meanwhile, to test the hypothesis using the multivariate correlation regression test. 


\section{Results}

In this study, data were obtained from test and non-test instruments. The variable of generic science skills was measured using a test instrument in the form of elaboration questions totalling 11 questions, the scientific attitude variable was measured using a non-test instrument in the form of a questionnaire totalling 35 statements, and the learning outcome variable was obtained from the daily test score of the coordination system which amounted to 30 questions.

\section{Data Description}

a) Generic Science Skills

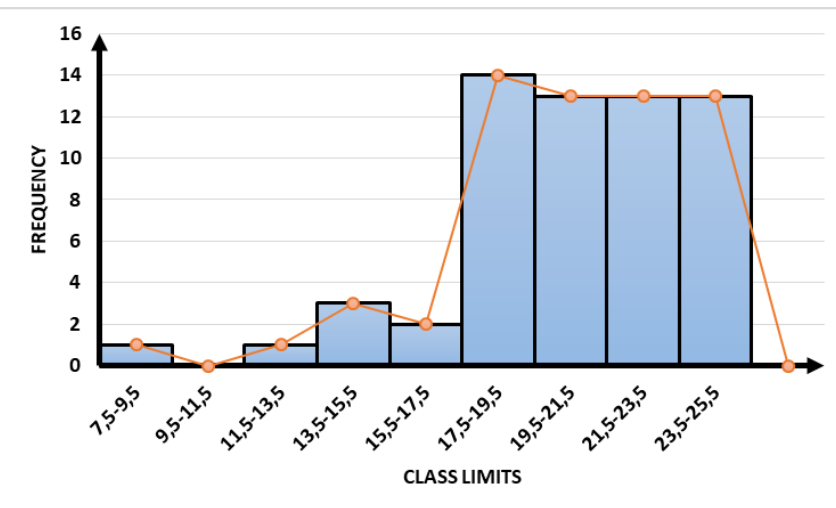

Figure 1. Histograms and Polygons of Students' Generic Science Skills Test Scores.

Figure 1 shows the generic science skill score data of students from groups A and B. The generic science skills score of students belongs to the acceptance criteria. It happened because 39 of the 60 students scored above average. Thus, the normal direction of the curve is skewed to the right.

\section{b) Sciencetific Attitude}

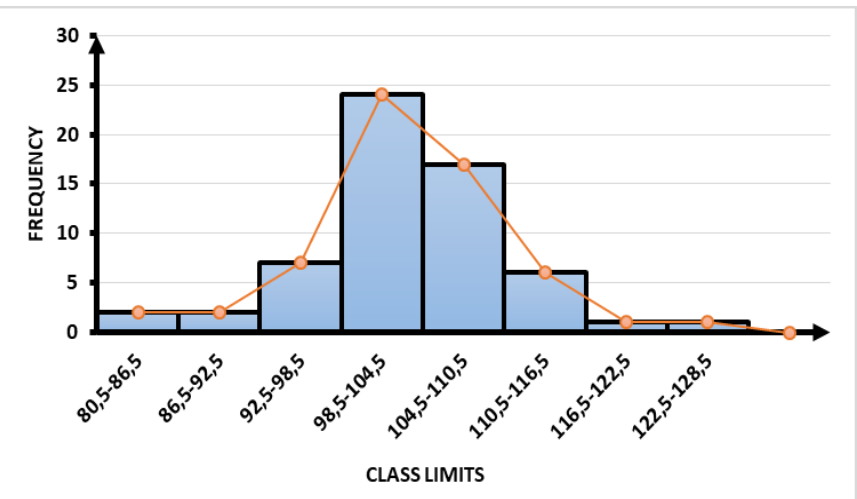

Figure 2. Histograms and Polygons of Student Questionnaire Scores.

\section{c) Learning Outcomes}

Figure 3 shows the data on the learning outcomes of students from groups A and B. The value of learning outcomes is classified into good criteria. It happened because 35 students scored above average. Thus, the normal direction of the curve is skewed to the right.

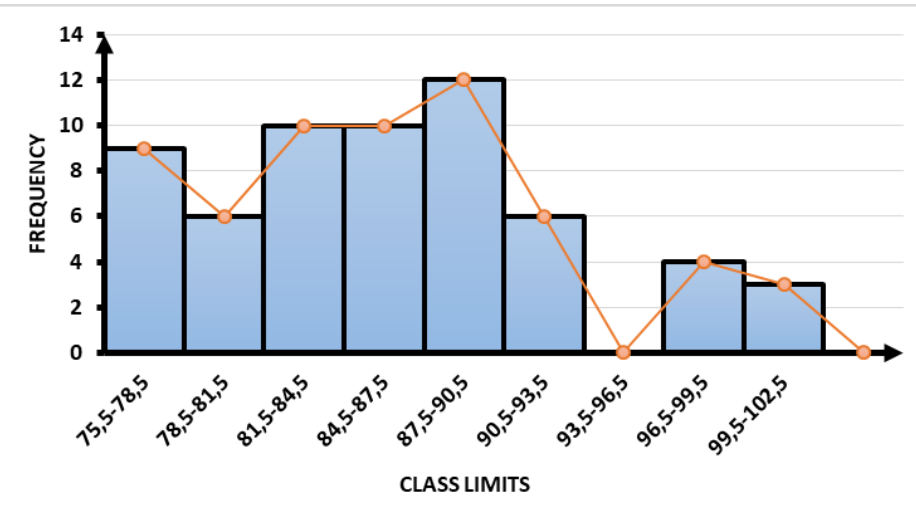

Figure 3. Histogram and Polygon Value of Student Learning Outcomes

\section{Hypothesis Testing}

Based on Table 1, the significance value obtained is 0.000 , which means a very significant correlation between generic science skills and scientific attitudes towards student learning outcomes. In addition, the correlation coefficient value $(\mathrm{R})$ was 0.623 , and the determination coefficient $\left(\mathrm{R}^{2}\right)$ value was 0.388 or $38.8 \%$. Thus, it can be concluded that the variable generic science skills and scientific attitude contributed $38.8 \%$ while the remaining $61.2 \%$ were other variables not examined in this study.

\section{Discussions}

The correlation between generic science skills and scientific attitudes towards student learning outcomes in the coordination system material has a correlation coefficient $(\mathrm{R})$ of 0.623 which means that the relationship between variables is muscular.

Based on the data obtained, generic skills have an average curve direction that is inclined to the right, and this means that the contribution made by generic science skills to learning outcomes is significant. In contrast to KGS, scientific attitudes have an average direction to the leftleaning curve. However, both generic science skills and scientific attitudes have a strong correlation to student learning outcomes.

The correlation between generic science skills and scientific attitudes towards learning outcomes is supported

Table 1. Hypothesis Testing with Multivariate Correlation Test

\begin{tabular}{|c|c|c|c|c|c|c|c|c|c|}
\hline \multirow{2}{*}{ Model } & \multirow{2}{*}{$\mathrm{R}$} & \multirow{2}{*}{$\begin{array}{c}\mathrm{R} \\
\text { Square }\end{array}$} & \multirow{2}{*}{$\begin{array}{c}\text { Adjusted R } \\
\text { Square }\end{array}$} & \multirow{2}{*}{$\begin{array}{l}\text { Std. Error of the } \\
\text { Estimate }\end{array}$} & \multicolumn{5}{|c|}{ Statistics } \\
\hline & & & & & R Square Change & F Change & df1 & $\mathrm{df} 2$ & Sig. F Change \\
\hline 1 & 623 & ,388 &, 367 & 5,442 & ,388 & 18,080 & 2 & 57 &, 000 \\
\hline
\end{tabular}


Prabowo et al. (2016), namely "There are skills that train the way of thinking and the skills of students in solving problems in science, namely skills generic science". Likewise with the opinion put forward by Gunada, Sahidu, \& Sutrio (2017) that "A scientific attitude is an attitude that must be present in a scientist or academic when facing scientific problems". The scientific problems faced by students will at least arise during the teaching and learning process. Benchmarking students' ability to solve problems that exist in the process of teaching and learning activities, one of which is to see the learning outcomes obtained. This is in line with the opinion expressed by Gagne in (Wahab, 2017) which states that "Learning outcomes are abilities that can be observed in a person".

This discovery is following various previous studies. Febriyanti, Ilyas, \& Cut (2014) explain that "The results of the correlation test between generic science skills and learning outcomes show that there is a positive relationship or correlation". In line with that, Lathifa (2019), in her research, stated that "There is a significant relationship between generic science skills and student learning outcomes". Students need generic skills to become successful learners in teaching and learning activities and face the world of work (Mustofa et al., 2018).

Furthermore, research conducted by Razak \& Rahmat (2018) also states that the calculation of the correlation between scientific attitudes and learning outcomes shows a fairly strong relationship. Other research that supports this statement is "The correlation between scientific attitudes and cognitive learning outcomes is a direct correlation (positive) (Putri et al., 2017)". Students' scientific attitude is an attitude that cannot be forced by someone but emerges from themselves, thus encouraging students to achieve learning goals, namely obtaining high and maximum learning outcomes (Razak \& Rahmat, 2018).

Then, research conducted by Martiningsih, Situmorang, \& Hastuti (2018) also said that "there is a correlation between generic science skills and scientific attitudes in terms of the cognitive domain of students". This also proves that generic science skills and scientific attitudes contribute to students to achieve learning outcomes that are in line with expectations. When students have good generic science skills, students will be able to solve existing science problems during learning so that they can understand the concept of learning. Likewise, when students have a positive scientific attitude, they will be more active in finding out and understanding the material taught, so that students' understanding of the material being taught will increase.

Martiningsih et al. (2018) explained that "students who have a good level of generic science skills would also help students understand concepts". Razak \& Rahmat (2018) stated that "The higher the scientific attitude of the students, the higher the student learning outcomes. Moreover, vice versa, the lower the student's scientific attitude, the student's learning outcomes are also decreasing".

Based on this, generic science skills and scientific attitudes are able to contribute to student learning outcomes. Thus, teachers need to mentor students in order to be able to develop and improve generic science skills and scientific attitudes to themselves.

\section{Declaration statement}

The authors reported no potential conflict of interest.

\section{Conclusions}

Based on the descriptions that have been put forward, it can be concluded that both generic science skills and scientific attitudes have a contribution to improving student learning outcomes. Therefore, generic science skills and scientific attitudes are factors that need to be continuously trained so that students can obtain optimal learning outcomes.

\section{References}

Anwar, H. (2009). Penilaian Sikap llmiah Dalam Pembelajaran Sains. Jurnalpelangi Iimu, 2(5), 103-113.

Astuti, R., Sunarno, W., \& Sudarisman, S. (2012). Pembelajaran Ipa Dengan Pendekatan Keterampilan Proses Sains Menggunakan Metode Eksperimen Bebas Termodifikasi Dan Eksperimen Terbimbing Ditinjau Dari Sikap Ilmiah Dan Motivasi Belajar Siswa. Jurnal Pasca UNS, 1(1), 2252-7893.

Brotosiswoyo, B. . (2001). Hakekat Pembelajaran MIPA di Perguruan Tinggi: Fisika. PAU-PPAI Dirjen Dikti Depdiknas.

Febriyanti, D., Ilyas, S., \& Cut, N. (2014). Peningkatan Keterampilan Generik Sains Melalui Penerapan Model Sscs (Search, Solve, Create And Share) Pada Materi Mengklasifikasikan Makhluk Hidup Di Mtsn Model Banda Aceh. Jurnal Biologi Edukasi, 6(2), 43-47.

Gunada, I. W., Sahidu, H., \& Sutrio, S. (2017). Pengembangan Perangkat Pembelajaran Fisika Berbasis Masalah untuk Meningkatkan Hasil Belajar dan Sikap Ilmiah Mahasiswa. Jurnal Pendidikan Fisika Dan Teknologi, 1(1), 38. https://doi.org/10.29303/jpft.v1i1.233

Hall, H. (2019). The Scientific Attitude, Not the Scientific Method, Is the Key. Science-Based Medicine.

Lathifa, N. N. (2019). Hubungan Pelaksanaan Praktikum Dan Keterampilan Generik Sains Dengan Hasil Belajar Peserta Didik Kelas Vii Di Smp Negeri 14 Bandar Lampung Pada Materi Pencemaran Lingkungan. Universitas Bandar Lampung.

Martiningsih, M., Situmorang, R. P., \& Hastuti, S. P. (2018). Hubungan Keterampilan Generik Sains Dan Sikap Ilmiah Melalui Model Inkuiri Ditinjau Dari Domain Kognitif. Jurnal Pendidikan Sains (Jps), 6(1), 24. https://doi.org/10.26714/jps.6.1.2018.24-33

Muspiroh, N. (2012). Analisis kemampuan generik sains 
mahasiswa calon guru biologi pada praktikum anatomi tumbuhan. Jurnal Science Education, 1(1), 1-15.

Mustofa, R. F., A., D. C., Suarsini, E., \& Saptasari, M. (2019). The Problem-Based Learning Model and Students' Generic Skills of the Faculty of Teachers Training and Education the Universitas Siliwangi Tasikmalaya on the Animal Structure Course. International Journal for Educational and Vocational Studies, 1(1), 53. https://doi.org/10.29103/ijevs.v1i1.1466

Mustofa, R. F., Aloysius, D. C., Suarsini, E., \& Saptasari, M. (2018). The Correlation between Generic Skills and Metacognitive Skills of Biology Education Students in Tasikmalaya Indonesia Through Problem-Based Learning Model. The Journal of Social Sciences Research, 5(Special Issue 5), 662-667. https://doi.org/10.32861/jssr.spi5.662.667

Prabowo, L. B., Ngazizah, N., \& Sriyono. (2016). Analisis Keterampilan Generik Sains Siswa Sma Negeri Kelas X Se-Kabupaten Purworejo Dalam Pembelajaran Fisika Tahun Pelajaran 2015/2016. RADIASI: Jurnal Berkala Pendidikan Fisika, 8(1), 51-54.

Putri, A. T., Idram, I., \& Yennita. (2017). Analisis Korelasi Sikap Ilmiah dan Hasil Belajar Kognitif Siswa Melalui Model PBL. Jurnal Pendidikan Dan Pembelajaran Biologi, 1(1), 1-9.

Razak, F., \& Rahmat, K. (2018). Pengaruh Sikap Ilmiah Siswa Terhadap Hasil Belajar Materi Bangun Ruang Siswa Kelas Viii Smp Negeri 3 Minasatene. Jurnal Musharafa, 7(1).

Sadia, W. I. (2014). Model-Model Pembelajaran Sains Kontruktivistik. Graha Ilmu.

Sudjana, N. (2014). Dasar-Dasar Proses Belajar Mengajar. Sinar Baru Algesindo.

Sugiyono. (2012). Metode Penelitian Kuantitatif Kualitatif dan R\&D. CV Alfabeta.

Sukaesih, S. (2011). Analisis Sikap Ilmiah dan Tanggapan Mahasiswa Terhadap Penerapan Model Pembelajaran Berbasis Praktikum. Jurnal Penelitian Pendidikan, 28, 77-85.

Wahab, J. (2017). Belajar dan Pembelajaran Sains. Pustaka Reka Cipta.

Yogihati, C. I. (2010). Peningkatan Kualitas Pembelajaran Fisika Umum Melalui Pembelajaran Bermakna Dengan Menggunakan Peta Konsep. Jurnal Pendidikan Fisika Indonesia, 6(2), 104-107. https://doi.org/10.15294/jpfi.v6i2.1121 